\title{
To Make See and to Let Die: photography and testimony
}

$>\quad$ Gustavo Racy

University of Antwerp/CAPES Foundation, Antwerp, Belgium | Ministry of Education of Brazil, Brasília, Brazil.

gustavo.racy@uantwerpen.be

\section{ABSTRACT}

The focus of this article is a speculative argument on the relation between photography and testimony as one that situates the viewer on a particularly powerless, but responsibility-laden position. Articulating Nilufër Demir's viral 2015 photograph of Aylan Kurdi, and Walter Kleinfeldt's 1918 photograph of an unknown fallen soldier, as images bearing the marks of shifts in biopolitics, the article takes up on Walter Benjamin, Michel Foucault, Georges Didi-Huberman and Giorgio Agamben, and reflects upon the possibility of addressing and responding to images beyond a moral level. As such, it inquires on the need to relate to images on a level that considers power relations. Ultimately showing that observers, or viewers, of photographs are necessarily tied to the unfolding of human history, no matter how distant they may be from its events, the article proposes a response to the need of assuming a political stance when facing images.

Keywords: Photography, testimony, power, biopolitics, refugees, World War I.

\section{Walter Kleinfeldt and the Unknown Soldier}

In the aftermath of a bloody battle, a photograph taken by 16-year-old Walter Kleinfeldt, a German soldier fighting in Flanders, presents us with Christ as a hopeless redeemer. A desperate figure, impotent in face of the massacre, unable to reach the fallen soldier in front of him. In the foreground a blurred-face corpse, his face pressed to the ground, backwards to Christ. The figure could be that of a homeless, sleeping person, but the distressed position of the arms, and the arched body - not to mention the landscape - do not lie, denouncing a life that is no more. Beyond the soldier, occupying the vantage point we emulate, the photographer makes itself present. Did Kleinfeldt come across the body on a round? Did he know the soldier? Was he there when he died, or, maybe, was it Kleinfeldt who killed him on a desperate act of self-defence? ${ }^{1}$ 


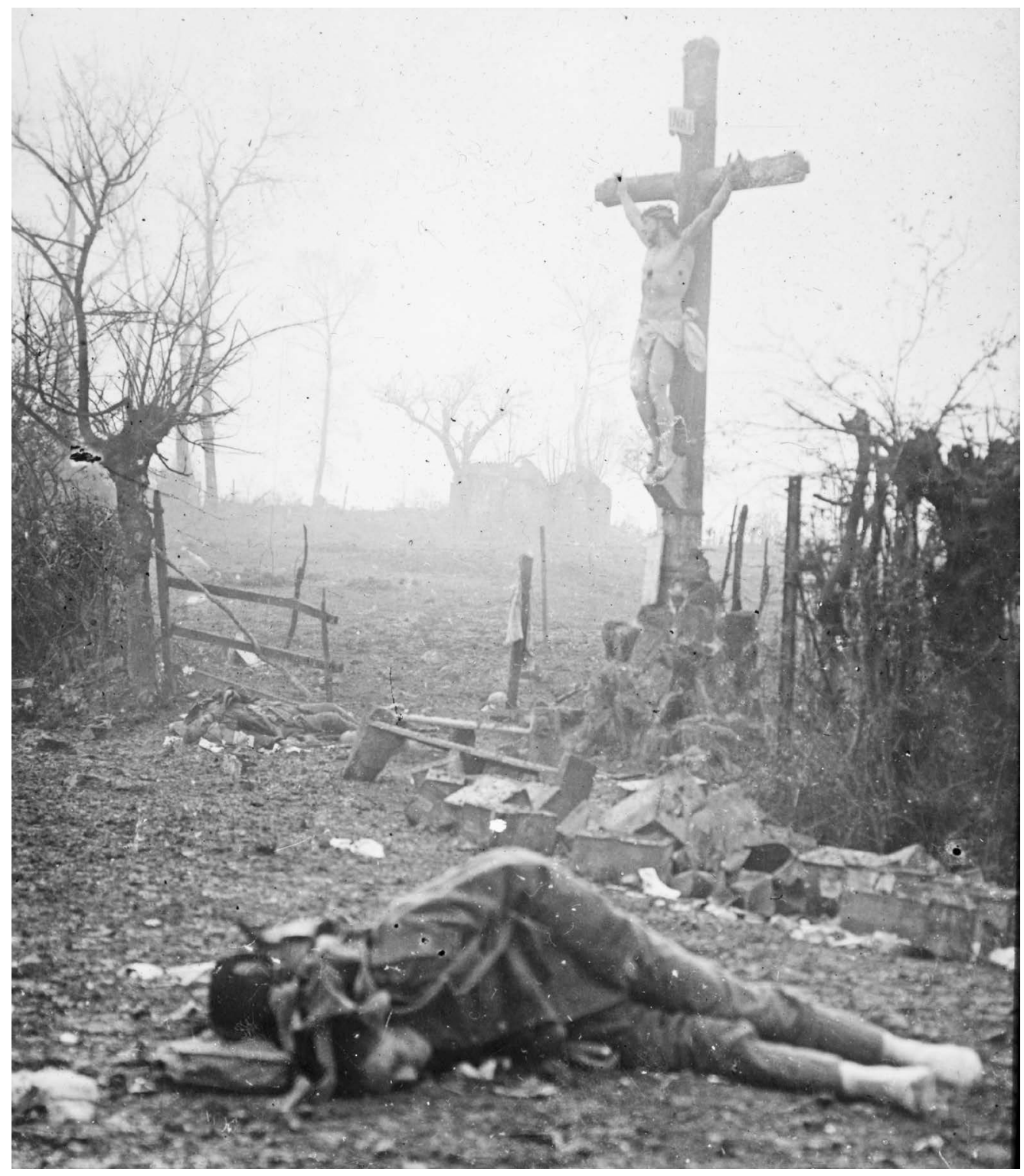

FIGURE $\mathbf{N}^{\mathbf{0}} \mathbf{1}$

Walter Kleinfeldt, 1918. Fallen British soldier. Zwartemollenhoek, Belgium. Courtesy of the Kleinfeldt Archives, Tübingen/Germany.

History has bequeathed us with the final words of many personalities. It is known, thus, that on their deathbeds, Goethe asked for more light and, some decades later Turner claimed the Sun to be God. What must have been the soldier's final words? Did he even have the time to proclaim them? Regardless of what they might have been, final words are everlasting only for the few, selected men and women who, for one reason or other manage to enter the long roll of names that are declared worthy of being engraved in the imaginary history of humankind. Yet, the soldier and all these 
personalities have something in common: they all died alone. Whether surrounded by many or in the solitude of a cell, death is a personal, individual experience. We might testify to someone's death, we might witness the end of their life, but it is impossible to go through it with them. Following Martin Heidegger, Giorgio Agamben (1999) recollects that dying is the individual experience of undergoing death as a Being. As such, death, as the 'measureless impossibility of existing [becomes] the way in which man, liberating himself of his fallenness in the world of the "They" (das Man), renders his factical existence possible' (Agamben 1999:75).

If the soldier's final words are unknown, however, we know his last image. Moreover, there is no reason to think they belong to different orders. Just as Goethe's or Turner's final words, the unknown soldier's image demands our reflection and time. It is the image itself which will provide a meaning that, if it does not allow understanding the reasons and causes of World War I, brings this fringe of history closer, updates it to the present. In order to do so, it is necessary to further analyse Kleinfeldt's photograph, to which Roland Barthes's (1984) distinction between punctum and studium may be particularly useful. As Roland Barthes (1980) pointed out, punctum and studium are usually in relation, although not all photographs present a punctum. Usually, photographs that tend to be unary, that is, photographs that "transform emphatically the "reality, without doubling it, without making it falter"'2 (Barthes 1984:66), tend to present no punctum. '[F]reed from useless accessories' (Barthes 1984: 66), which is usually the case of journalistic photography, unary photographs tend to be received once and immediately. It so happens, however, that, sometimes, unary photographs can present something that pierces the viewer's gaze with a detail that attracts them to it. The studium of Kleinfeldt's photograph seems obvious: this is a photograph of a war massacre. Whether an air or an artillery raid, viewers finds themselves in front of a battlefield. It is an interesting play between punctum (the interpretive, subjective take on the image) and studium (the informed reading of the photograph) however, which composes the richness of this image. More precisely, it is the relational depth of field, which, presenting a play of sharpness and blur between Christ and the soldier, resumes the importance that this image may have. This play between sharpness and blur makes Kleinfeldt's photograph particularly rich and different from the remainder of his images, which mostly depict daily banal activities: smoke breaks, a pose in front of a church, and so forth. Furthermore, an interpretation of this image grounds a link between studium and punctum offering the viewer with two complementary readings.

The first reading regards the relation, made above, of a death that turns its face away from the divine; death is no more a natural episode, a coronation of life, leaving the mark of the individual in the community and in the lives to come. In this sense, the sharpness of the statue makes a statement which may be seen as either revolt and/ 
or claim for atonement. This relation is further enriched by the close observation of the angle of Christ's statue in relation to the soldier. Christ, too, has His face turned away from the soldier. Sculpted in His final moments, still alive, thus, Christ is brought back to His human essence. Dramatic, this photograph in many ways may be related to the Passion. Just as Jesus was presented to the crowd by Pilate with the words Ecce homo, so too Kleinfeldt present us with the soldier: "here is the man, through your hands he has died". This composition reinforces the solitude of death and the shift occurred in twentieth-century warfare, in which territorial sovereignty became the core of state relations.

The complementary reading is the symptom behind the choice of focus. By blurring the soldier's face, Kleinfeldt too, turns his face away from death. We are not allowed to pay our tributes to the fallen soldier, because we cannot look at his face. This is the image of the anonymous soldier to which the photographer, unable or choosing not to show the face of the dead person he portrayed, adds the divine to the sphere of testimony. Thus, Kleinfeldt's image communicates the loss of meaning in the experience of death, as well as its incommunicability: death separated from the human sphere, put apart from human grasp. Powerfully critical, this photograph is a manifesto against both the loss of transmission, and the control over the right to live and die. By the diagonal play of focus between foreground and middle ground, between the blurred face and the statue, Kleinfeldt denounces the caesura between life and death, between transmission and loss of experience. On the other hand, it is also a diagnosis. It is Kleinfeldt, as a subject that, by looking at death, chooses not to reflect upon it. And, instead of suggesting us to think about it - its causes, the horror of war, and so forth - makes explicit to first and foremost acknowledge its existence. In a compelling way, the photographer managed to transmit his own loss through the image.

\section{Aylan Kurdi and the viral image of death}

Whereas Kleinfeldt's images remained unknown for a century, ${ }^{3}$ a second image - in fact a series of images depicting death - became viral in 2015, causing commotion, rage and diverse responses from the international community (NGOs, State authorities and the general public) within different political spectres. Taken by Nilufër Demir, the image of 3-year-old Syrian-Kurdish Aylan Kurdi's body ashore, lying face down on a Turkish beach while a Turkish officer register the occurrence, moved the world. Heavily reproduced and exploited, Kurdi's image became the synthesis of the refugee crisis. The mere reproduction of such image risks falling into an exploitation of humanitarian crisis and, on a deeper level, of human life, as even Susie Linfield, staunch defender 
of photojournalist was able to acknowledge, as the 'depiction of powerless, vulnerable people is a fraught enterprise that can easily veer into condescension' (emphasis in original) (Linfield 2010:10). Nonetheless, the cross reading of Demir's and Kleinfeldt's images lead us to a reflection on the importance of images amidst political issues. As it will be shown, this reading will expose the shift operated in the political meaning of photography by not only its final-product, the image, but also more specifically, the role of the photographer.

Before that, however, an important ethical consideration must be made. The viralisation of Demir's work and the reproduction en masse of Kurdi's image became a means for exploiting suffering, death, fragility and catastrophe in monetary terms. I do not believe Demir's work to be unethical, but its exploitation once in the media. In that sense, a double exploitation happens, that of Kurdi's and that of Demir's work. This observation led the investigator to consider the possibility of not reproducing the photograph in this article, once it could further contribute to this exploitation "regarding the pain of others" (Sontag 2003). Even though, in a contemporary account, Susie Linfield (2010) positively argues in defence of the need to see these images of horror and suffering, in here, it matters not condoning with a reproduction of the image that veers into profitable consumption. As Mark Reinhard (2012) observes, Linfield's view misses the importance of the forces at play in the control, making, and circulation of photographs. This, however, is vital for the goal of this article, which consists in discussing the position of the viewer, who is an integral subject of the "civic negotiations" (see Azoulay 2008) through which photography comes into social existence. As I wish to discuss through Giorgio Agamben and Georges Didi-Huberman's thinking, it is important to look at suffering. It exists, and it testifies to an essential component of social reality. If calamity, war and catastrophe photographs simply "flare and fade" (Sontag 2003), as intermittent pieces of information, that is because the modern condition subjugates us to numerous stimuli of which we are not always able to cope (Simmel 1950). Not producing images of our harsh social reality at all, however, in some way equals silencing, or mystifying the truth, as Agamben $(1998,1999)$ and Didi-Huberman (2003) agree regarding Auschwitz. Therefore, more than producing or not, looking or not, we lack, firstly, new ways of looking at these images, new ways of looking and reflecting about the complex situation that the production and consumption of such images, as well as the images themselves, engender.

Regarding Demir's photograph, not only was it exploited as a symbol of the "refugee crisis", appealing to worldwide sensibility - something indeed necessary, but by itself unable to bring the question to an end (see Benjamin 2005b) - it also became a sort of legal trademark of the tragic end of a child's life. The politics involved in the reproduction of the image displays a problematic situation over copyrights. Besides 
becoming a viralised image of the refugee's situation, which, as it was just declared, brings up an ethical question, there resides, in the core of the social life of the image, a legal claim over its property. Legally, thus, the image of Aylan Kurdi, belongs to an enterprise that decides under which economic circumstances (here the economic sphere is essential), it can or cannot be reproduced. This is in tune with the argument this article will soon bring forth with Agamben, according to whom the sphere of right plays a major part in the existence of the testimony. The legal protection over the economic relation established on the property of the image adds yet another ethical question to the matter. To what extent can images, especially those that manage to achieve the social dimension that Demir's obtained, be claimed as private, for instance? The refugee crisis has been declared the worse humanitarian crisis after WWII. In that sense, how fair is it to deny the free use of a reality that has been declared to be touching most parts of the world? Considering these questions, there seems to be no need for reproducing the image. As I look at it on the computer screen, I realise it is not necessary to reproduce this image yet again. It is widely known and easily found, since extensively reproduced. What matters here is putting it in relation to Kleinfeldt's, as an indicator of important changes within contemporary political life, which might allow us looking at photographs differently and, in this case, honouring the image of Aylan Kurdi.

The image we first came to know of Aylan showed him face-down, his head close to the water and turned sideways. We cannot see his face, but there is no need for that in order to understand the message: you are facing the tragedy of a young child who has drowned. Tragedy? Maybe. Tragedies, however, in its classical sense, deal with a closed plot, counting with beginning, middle and end (see Aristotle), which leads Benjamin to understand tragedy as a Greek fatalist form that deals with destiny (Benjamin 2004, 2009). Destiny is that which is subject to natural history. It obeys the laws of nature of which none of us can escape. Tragedies are, this way, inevitable. Aylan's death, as well as that of his mother, brother and thousands of other people, however, were not inevitable. They were the by-products of society. The photograph, taken by Nilüfer Demir took root in the world through the news and social media, especially. The rest of the story is well known. It is not of that particular image that I want to talk about, however, but of one taken in the stream of photographs shot during the Turkish authorities' work in the area. Shot by Nilüfer Demir, the photograph portrays Kurdi's body in the same angle as the first one, laying ashore. Next to Kurdi's body, closer to the camera and backwards to the lenses, a man stands up resting his weight over his left leg and bending his neck down. His bent elbows and the tip of an angular object suggests he writes down the scene. The beret, boots and armband on the left arm leave no clue he is an agent of State. Indeed, his fluorescent vest denounces his position, having “Crime, Scene, Investigation" stamped in Turkish. 
Firstly, by not being able to distinguish both Kurdi's and the man's face, we are presented with bodies. Surely, there is clear evidence that these are the bodies of a child and of a grown-up, and that they are both male bodies. However, the nondepiction of faces does not allow us to recognise the individuality of such individuals. What we see on the right hand is a uniformed man representing the State through the sayings "Crime Scene Investigation" written in Turkish on the upper back of his vest and, to the left, the image of death. Deprived of name, as we first came to know him, Aylan's death is every death. It could be our own or our neighbour's child, it is any and every dead. It is, quite simply, death as such.

Secondly and perhaps less evidently, since many versions of Demir's account of the happening excluded the second individual in the image, if we agree that the first relation we create with this image is that of looking at death, there is a power relation between Aylan and the State agent that seems to write down details of the happening. As we shall see, this relation extends to the photographer too. To understand it, we need to go back to the genealogy of the testimony. On his discussion about what he names the "remnants of Auschwitz", Giorgio Agamben $(1998,1999)$ shows that the genealogy of the witness in Roman Law gives rise to a confusion between ethical and juridical categories. Latin language, and Law, used to differentiate terms from whence we derived the contemporary idea of testimony. The first one was terstis. Etymologically, terstis stood as the one who put him/herself as a third party (terstis) 'in a process or in a litigation between two contestants' (Agamben 1998:15). The second word was superstes, indicating the ones who, having lived something through could therefore render a testimony. In this sense, the distinction between terstis and superstes must be recalled in order to interrupt the equalling of morality and ethics, law and justice. 'As jurists well know, law is not directed toward the establishment of justice. Nor is it directed toward the verification of truth. Law is solely directed toward judgment, independent of truth and justice' (Agamben 1999:18). It follows that the end of law is the production of a res judicata. Thus, a sentence that follows judgment becomes essentially an act void of meaning, for 'judgment aims neither to punish nor to extol, neither to establish justice nor to prove the truth' (Agamben 1999:19). This being, 'punishment does not follow from judgment, but rather ... judgment is itself punishment (nullum judicium sine poena)' (Agamben 1999:19). The presence of law is a priori, thus, punishment regardless of truth or justice. However, in which way does this relate to the photographs addressed here? The answer lies on an essential testimonial character not of the photograph, but of the photographer.

Therefore, by personifying the State, and not only that, but by watching and taking notes (the apparently bent elbows and neck, as well as by a small glance of what appears to be a notebook one deduces the agent takes note), the State-agent in the 
photograph puts himself as the terstis, as the one who, by documenting the event before taking any other action, arrives as the third party between two opposite interests. Interests? Yes. The "Crime, Scene, investigation" stamped in Turkish in the upper back of the agent's vest bears the sign of a judicial domain. The agent is the third party between the State, an agent of the State's sovereign power, and the event, which, as we have come to know, refers to the resulting of the inability to deal with the political crisis in the Middle East. The tagging, the categorisation, the legal procedure turns death into a juridical event. To which the agent, whether intentional or not, acts as a judgemental terstis. On the other hand, behind the camera, the photographer gives testimony as superstes. Here resides the power of the image: the photograph does not judge but brings forth 'that which makes judgement impossible' (Agamben 1999:17). It takes the event - which depicts the absurdity of legal procedure regarding the refugees - only this time, beyond the sphere of law. The image that shook people worldwide became a platform for an immediate political solution for the refugee crisis. As superstes, the photographer shows that a 'non-juridical element of truth exists such that the quaestio facti can never be reduced to the quaestio iuris' (Agamben 1999:17).

Here is where the political argument comes forth with greater strength. The relation between death, terstis and superstes makes explicit what, in Kleinfeldt's image, is only hinted at. In his image Kleinfeldt is - as perhaps all photographers may be superstes whereas the terstis is the observer, but only on a historical perspective. In that sense, Christ appears to remind the viewer of the distinction between the ethical and the legal. 'Ethics is the sphere that does not know guilt nor responsibility: this is, as Spinoza knew, the doctrine of beatific life. Assuming a guilt and a responsibility ... means leaving the ambit of ethics to enter that of right' (Agamben 1998:22). As such, Kleinfeldt's image, dispossessed of judgement, comes closer to transmitting the experience of barbarity as the impossibility of transmission. In consonance with Benjamin's observation (1996), Kleinfeldt's image transmits the impossibility of the transmission of experience, because it transmits no causes, nor does it transmit its content as the effect of something beyond itself. It testifies, however, supported by a powerful reflection on the meaning of life and death.

Changing our focus to the photograph of Aylan, what we have is a shift in the composition of the testimony. We are put in front of the judge, who turns backwards to us, while the victim, on the contrary, turns its face towards us. There is no divine in the photograph. The addition of the terstis to the image brings us forth to a different relation to life and death. Now, both life and death are detached from the sphere of ethics and inserted in the sphere of law. By playing the intermediary, slightly closer in the frame's foreground, the terstis cuts the communication between the victim and 
the superstes. The importance of the photograph arises when, as a cut itself, it manages to seize the moment when the judgement is made. If Kleinfeldt's photograph denounced the increasing control over life, Demir's photograph denounces the apex of control over death. There is a significant qualitative change over the role of the viewer who takes the time to reflect on the role of an image. Although powerless, we are left with the role of superstes.

\section{Morality and politics of the photograph and the place of the witness}

Kleinfeldt's and Demir's photographs are, to a certain extent, parallel. Both photographers present us with that 'new kind of misery' of which Walter Benjamin talks about (Benjamin 1996a:115); a misery that extinguished the link between humankind and its cultural heritage, relinquishing the value of a truthful, meaningful experience possible to be transmitted from mouth to mouth. In Kleinfeldt's case, the diagnostic is precise. The dead soldier, and Kleinfeldt himself could just be the subjects Benjamin had in mind when observing that a 'generation that had gone to school in horse-drawn streetcars now stood in the open air, amid a landscape in which nothing was the same except the clouds and, at its center, in a force field of destructive torrents and explosions, the tiny, fragile human body' (Benjamin 2005a:732). In fact, with World War I, according to Benjamin, something in the core of human condition was lost. From then on, observing the muteness of the soldiers that came back from the front, the ability of transmitting our meaningful experiences was lost. Humankind would have to survive culture itself in order to start again.

Nonetheless, does Kleinfeldt's photograph not speak to us? Doubtlessly it is not possible to say that, from his image, we are able to grasp the horror and all of the existential weight of World War I. We know the reasons, causes, and outcomes of the war and yet we cannot draw, by looking at the image, that which Benjamin would call a "truthful" experience (Erfahrung). A type of experience, which, as the root (fahr) of the German word express, transmits a movement between places (expressed by the affix -ung), a relation of "having-been-there". What we are left with is, precisely, the impossibility of drawing, from the facts depicted, any kind of experience. We are left without any mystery. In Kleinfeldt's and Demir's images, all is unveiled, and maybe because of that it is so difficult not precisely to draw something from them, but to know what to do about or with them. It is important, finally, to stress that the loss of experience relates more to a loss of transmissibility than to any kind of phenomenological or existential experience. It is the ability to transmit, and within transmission, creating 
a shared co-experience of the human heritage that we have lost. After all, as Georges Didi-Huberman (2003) and Giorgio Agamben $(1999,1998)$ made it clear, to talk about disaster in the level of the unspeakable is relegating it to mystical adoration. As hard as it might be, as much error as we can incur to when dealing with it, we must talk about Kleinfeldt's and, more importantly, Kurdi's image, as much as we must talk about many other images of the sort. If the need for this is not wholly clear, since there is no obvious reason why we should be attracted towards images of death or violence, the opposite situation, that of not looking and not talking about it seems, contrary to a common opinion, worse. If, on the one hand, the reproduction of these images may incur into an exploiting and spectacularising images of violence, 'it is refusing to look that makes one an "accomplice", whereas looking frees viewers from complicity by forcing them to respond' (emphasis in original) (Reinhardt 2012:39). It is precisely this response that matters here, and thinking of this response is the challenge of the critique that we face.

Although they operate in different ways, what both Kleinfeltd's and Demir's images do is denounce the existence of disaster caused by a sovereign power that, as declared by Michel Foucault (2005), makes live and lets die. In other words, they denounce power as an exercise that can easily go awry. Well resumed by Giorgio Agamben (1999:82), in

its traditional form, which is that of territorial sovereignty, power defines itself essentially as the right over life and death. Such a right, however, is by definition asymmetrical in the sense that it exerts itself above all from the side of death; it concerns life only indirectly, as the abstention of the right to kill.

With the development of a disciplinary society, from the seventeenth century onwards, with the birth of disciplinary sciences and the police, 'sovereign power is progressively transformed into what Foucault calls "biopower." The ancient right to kill and to let live gives way to an inverse model ... which can be expressed by the formula to make live and to let die' (emphasis in original) (Agamben 1999:82-82). As Benjamin had observed 40 years prior to Foucault, human body, human biological life, was put in the centre of the force field in which power is exercised by, first, granting the right to live, and later granting the right to die. The images we have looked at transcribe us precisely within this reality. Kleinfeldt's dead comrade and the hopeless Christ personify the equation of the traditional territorial sovereignty, denounced by the military uniform and strengthened by the symbolism of Christ, which marks the theological foundations of sovereignty. Demir's image, on the other hand, conveys the inversion of the equation, almost completely void of symbolism if not by the State-agent, which, different than a soldier, is there to impute a legal procedure. In addition, it bears the mark of "letting die" as the sea lets a children's body be washed ashore. 
Considering Benjamin's loss of experience and Foucault's critique of sovereignty, what can be made of such photographs? How do we understand them beyond this relation implied in the contents of the images themselves? Dedicating ourselves more exclusively to Nilufër Demir's photograph, we will see that the answer is twofold, and, although, both sides have already been touched upon, we will go back to them in order to conclude this enquiry. First, it is necessary to question the effects of photographs in contemporary visual culture inquiring such effects within the confusion made between the moral and the ethical spheres. Secondly, the answer relies in the shifting meaning of the author.

As Nadine El-Enany (2016:13) correctly asks, what 'was it about the photo of Aylan Kurdi that so galvanized Europe's public over the question of refugees?'. After all, this was not, indeed, the first child to drown fleeing with his family to Europe. The fact is that as Susana de-Andrés, Eloísa Nos-Aldás and Agustín García-Matilla (2016), images transform, they cause commotion and generate responses. Journalistic photographs, specifically, have a long tradition and a secured place 'in the registering of political conflicts, wars, tragedies and confrontations' (de-Andrés et al. 2016:30). Using Demir's viral photograph - one before the photograph we used here, depicting Aylan alone - as a case study, the researchers investigated how, exactly, responses to images are created specifically as social actions. Drawing on previous studies on the relation between media images and decision making, the authors investigated how Demir's photograph allow generating a 'reflection around the role of the image in causing solidary reactions on an international scale' (de-Andrés et al. 2016:30).

Interesting and important as it may be, de-Andrés, Nos-Aldás and García-Matilla's analysis between iconography, iconology and ethics, resumes social action to Google searches on terms "Syria" linked to "refugees," "immigrants" and "aylan". If, on the one hand, the incredible increase of Google search terms shows the strength of one single photograph to situate a political question, on the other, the "viralisation" of the image, falls short in actual, effective engagement. Again, with Nadine El-Enany (2016), one may wonder if the commotion caused by the photograph was not caused by Aylan's fair, white skin, 'aptly illustrated by the \#CouldBeMyChild hashtag, which was trending on Twitter following the discovery of Kurdi's body' (El-Enany 2016:13). The mere questioning of such possibility points out to an essentially moral response regarding Demir's image; this stance is also testified by way in which the spread of the image influenced the Google search to show a change of vocabulary from "immigrants" to "refugees". 
This distance between the concept of immigrant and refugee marks not only a different meaning; it also supposes a political turn in the treatment and comprehension of displaced persons, since refugee implies an institutional approach of reception (deAndrés et al. 2016:33).

As it operates a change of discourse, the photograph indeed can be said to be transformative and, in case of Demir's photograph, de-Andrés, Nos-Aldás and GarcíaMatilla (2016:35) declare it to be 'a nodal image in a civil reaction, as active mental thought in the ethical and political debate'. They conclude by declaring that Demir's photograph brings about the 'question of the power of social change obtained by the dialogical and overcoming factor of open, reflexive, creative, political and responsible intervention over the image' (de-Andrés 2016:36). This goes in hand with the study by Isidoro Arroyo-Almaraz and Raúl Goméz Díaz (2015) on the moral responses digital tools may provide, in which "moral judgement" is understood as a habit that tends to universality. Based on psycho-pedagogical moral schemes, the researchers conclude that, when it comes to digital media, the presence of real people, instead of animatronics representing actual persons, influences the resolution of moral dilemma and coherence of moral responses.

What does this response, either in de-Andrés, Nos-Aldás and García-Matilla or in Arroyo-Almaráz and Díaz, mean? If responses, in the former, are related to social actions, in the latter, they stand for a habit; but in both, responses refer to a judgment over the correct or incorrect behaviour when faced with a dilemma. This suggests that being in front of Demir's image implies the need for a response filtered by the correctness or incorrectness of the situation, a civic response, thus, operating within the realm of institutional relations. As Nadine El-Enany (2016) comments, Demir's image may have served white Europeans to see 'the dehumanisation of refugees as merely an expression of anti-migrant sentiment, or different values, or viewpoints in what is presented as a fair debate on migration' (El-Enany 2016:14). What El-Enany accuses, furthermore, is that the discussion and response that emerged from the wide dissemination of the photograph lies a moral judgment that in fact revolves around previously conceived racism, which causes caesura 'in the biological continuum of the human species' (Agamben 1999:84). If Kleinfeldt's anonymous soldier becomes an image of war itself, on a closer look, Kurdi's non-anonymity does not dignify the child. On the contrary, it serves to turn him into a demographic (1 of X dead), into an image of a people (the Kurdish), and an image of a population (the refugees). Surprisingly, this is exemplified precisely by the responses analysed by de-Andrés, Nos-Aldás and García-Matilla and named by Arroyo-Almaráz and Díaz as "moral responses". It is the categorisation of "refugees" and so on, that isolate a population into another zone in the biological continuum, once it hierarchises, qualifies and contrasts different people 
by their physiognomic characteristics. Thus, a so-called moral response produces the res judicata, in Agamben's $(1998,1999)$ understanding, and after which law cannot go any further.

However, the understanding of the moral response to the photograph as a judgement and its confusion with a juridical logic does not empty the potential of the same photograph. Nonetheless, it helps to elucidate the distinction between authors' viewpoints - social actions versus unconscious racism - and how these sentiments interfere with the way we look at images of our social reality. The fact, however, is that these images unfold from conscious political choices that result from the dynamics of sovereign power - that of making live and letting die - which grounds contemporary society. Moral responses imply assuming a responsibility that, as it has been discussed so far, and as the vigilant gaze of the State-agent in the image denounces, is contaminated with a juridical weight. In this retroactive juridical logic, assuming such a moral responsibility meets its end precisely through the kind of emotional response of Twitter hashtags denounced by Nadine el-Enany, as well as boosted Google search terms.

Overall then, how is it possible to create a different relation between viewer and image? Is it possible to relate looking at images such as Demir's photograph without falling into this kind of moral response, yet not refraining from feeling? It is not because we feel moved by an image that we respond morally to it. In many cases, it might be just the opposite. Because we are expected to have a moral response, we feel moved by images. However, feelings and commotion are not to be questioned. To feel saddened, horrified, disgusted by the harsh reality and disasters that many people around the world endure is a human response that is as necessary and weighs as heavily as the rational response over the meaning, causes and consequences of such realities. Decisive in the way we relate to images is that many of them, as de-Andrés, NosAldás and García-Matilla (2016) observed is that they are able to transform discourse over events and therein lies a key factor for reshaping our relation to photographs, and visual images in general. For discourses are transformed not autonomously from the will of the viewer, but by the interdependence between photographer, photographed subject and the viewer, who compose the image.

In the cases chosen here, the transformation of discourse is made as the role of the photographer changes in each specific event, altering the nature of his or her testimony. The passing from Kleinfeldt, as a terstis, to Demir, as a superstes, equals the inversion of the equation of power from "making die and letting live" to "making live and letting die". If in the first case, we are put in a position of terstis ourselves, in front of a clear anti-war statement; in the latter, the photographer becomes superstes. Demir is unable 
to do anything, except of bearing testimony. With that, we are put in the delicate position between terstis and superstes; we either judge or we attempt to give voice to the event. To understand Demir's image as a "something" (an event, a being), that takes place. In Georges Didi-Huberman's (2003:39) words,

one must do with images, with all theoretical rigueur, that which we already do, more easily with language ... For in each testimonial production, in each act of memory, both - language and image - are absolutely solidary, not hesitating on exchanging their reciprocal gaps. An image often comes forth where the word seems to fail; a word often comes forth where imagination seems to fail.

Understanding the image as a testimony means to understand it as 'the system of relations between the inside and the outside of langue, between the sayable and the unsayable in every language - that is, between a potentiality of speech and its existence, between a possibility and impossibility of speech' (Agamben 1999:145). While the image offers us a testimony and forces us to claim a position as superstes or terstis, it offers the possibility of claiming a position that makes justice to the subject portrayed, in the measure that it depicts 'the possibility that language does not exist, does not take place' (Agamben 1999:146). This is precisely, according to Agamben, what the subject is. What Demir's photograph gives us is the possibility to understand the process of subjectification and desubjectification since in its composition, it problematises the field of forces that determines 'currents of potentiality and impotentiality, of being able not to be and not being able not to be' (Agamben 1999:148).

By forcing us to take a stand as witness as superstes or terstis, we are put in a position that expresses the paradigm of our times, of which the limit situation was reached in the extermination camps of World War II. Furthermore, it adds a third relation of testimony, that of the auctor. The auctor appears in Latin originally as a "person who intervenes in the case of a minor ... in order to grant him the valid title that he requires' (Agamben 1999:148). This term also relates to "vendor" and, later, "witness". The fact that the term referred to "vendor" implies a relation of transfer of property "as a convergence of at least two parties in a process in which the right of the acquirer is always founded on that of the seller, who thus becomes the buyer's auctor' (Agamben 1999:149). Thus,

auctor signifies the witness insofar as his testimony always presupposes something - a fact, a thing or a word - that pre-exists him and whose reality and force must be validated or certified ... Testimony is thus always an act of an "author": it always implies an essential duality in which an insufficiency or incapacity is completed or made valid (Agamben 1999:149-150). 
That being, what happens is the formation of a unity between author, viewer and the subject portrayed? Only through this triad is it possible to understand the process of subjectification and desubjectification, which may allow us to bear witness. Whether we chose to be terstis or superstes, we also become auctor, since we bear witness to something that pre-exists us. Thus, it is only as superstes that we might be able to survive, as Walter Benjamin had observed (1996, 2005a), our culture. To survive, this is the new inversion of bio politics in our time. It does not make live or die anymore. Instead, it installs a power of making see, thus allowing happenings to survive, while subjects to which these happenings refer to are left to die. In this dynamic, happenings survive as we become able to bear witness, 'to place oneself in one's own language in the position of those who have lost it, to establish oneself in a living language as if it were dead, or in a dead language as if it were living' (Agamben 1999:161).

Finally, if we are able to make a stand in front of images, claiming a position within the delicate power relations that involve ourselves as viewers, the author and, most importantly, the subject portrayed then, and only then, we might be able to cope with the necessary truth that 'nothing that has ever happened should be regarded as lost to history' (Benjamin 2006:390).

\section{Notes}

1. Kleinfeldt photographs were discovered by his son, Volkmar, in 2011. They were kept somewhere in Kleinfeldt's photography studio in Tübingen, which he opened in 1918. In 2014, the BBC Four produced a documentary revolving around the "forgotten photographs" of World War One (see BBC 2014; EllisPetersen 2014).

2. 'transforma enfaticamente a "realidade, sem duplica-la, sem fazê-la vacilar"' (in the original)

3. Kleinfeldt's photographs remained hidden (or forgotten) in the cellar of his photographic studio until they were found in 2014.

4. 'il faut faire avec l'image, em toute rigueur théorique, ce que nous faisons dejà, plus facilement sans doute ... avec le langage. Parce qu'en chaque production testimoniale, en chaque acte de mémoire les deux - langage et image - sont absolument solidaires, ne cessant pas d'échanger leurs lacunes réciproques : une imae vient souvent là où semble faillir le mot, un mot vient souvent là où semble faillir l'imagination' (in the original). 


\section{REFERENCES}

Agamben, G. 1998. Quel che Resta d'Auschwitz. I'Archivio e il Testimone. Torino: Bollati Boringhieri.

Agamben, G. 1999. Remnants of Auschwitz. The witness and the archive. New York: Zone Books.

Andrés, S., Nos-Aldás, E., \& García-Matilla, A. (2016). La Imagen Transformadora. El poder de cambio social de una fotografia: la muerte de Aylan. Comunicar. Revista Científica de Educomunicación, XXIV (47). [O]. Available: https://www. revistacomunicar.com/index.php?contenido=detalles\&numero=47\&articulo= 47-2016-03.

Accessed 9 February 2017

Aristotle. (Kindle Edition). The Poetics of Aristotle (S. H. Butcher, Trans.): Public Domain.

Arroyo-Almaraz, I., \& Gómez Díaz, R. (2015). Efectos no deseados por la comunicación digital en la respuesta moral. Comunicar. Revista Científica de Educomunicación, XXII (44). [O]. Available: http://www.revistacomunicar.com/ index.php?contenido $=$ detalles \&numero $=44 \&$ articulo $=44-2015-16$ Accessed 9 February 2017.

Azoulay, A. 2008. The civil contract of photography. New York: Zone Books.

Barthes, R. 1984. A Câmara Clara. Nota sobre a Fotografia. Rio de Janeiro: Editora Nova Fronteira.

Hidden Histories: WWI's Forgotten Photographs. 2014. [Television programme]. BBC. Broadcast: 20:00, 13 March 2014, BBC Four.

Benjamin, W. 1996. Experiência e Pobreza Magia e Técnica, Arte e Política. Obras Escolhidas (Vol. I). São Paulo: Brasiliense.

Benjamin, W. 2004. Fate and Character, in Walter Benjamin. Selected Writings (Vol. I. 1913-1926), edited by M Bullock \& MW Jennings. Cambridge; London: The Belknap Press:201-206.

Benjamin, W. 2005a. Experience and Poverty, in Walter Benjamin. Selected Writings. (Vol. 2, part 2, 1931-1934), edited by MW Jennings, H Eiland \& G Smith. Cambridge; London: The Belknap Press:731-736.

Benjamin, W. 2005b. Little History of Photography, in Walter Benjamin. Selected Writings. (Vol. 2, part 2, 1931-1934), edited by MW Jennings, H Eiland \& G Smith. Cambridge; London: The Belknap Press:507-530. 
Benjamin, W. 2006. On the concept of history, in Walter Benjamin. Selected Writings. (Vol. 4, 1938-1940), edited by MW Jennings \& H Eiland. Cambridge; London: The Belknap Press:389-400.

Benjamin, W. 2009. The origin of German tragic drama. Translated by J Osborne. London \& New York: Verso.

Didi-Huberman, G. 2003. Images Malgré Tout. Paris: Les Éditions de Minuit.

El-Enany, N. 2016. Aylan Kurdi: the Human Refugee. Law Critique 27:13-15.

Ellis-Petersen, H. 2014. How Germany was Crucified. The Daily Mail 08 March.

Foucault, M. 2005. Em Defesa da Sociedade: curso no Collège de France (1975-1976). São Paulo: Martins Fontes.

Linfield, S. 2010. The cruel radiance. Photography and political violence. Chicago: The University of Chicago Press.

Reinhardt, M. 2012. Painful photographs. From the ethics of spectatorship to visual politics, in Ethics and images of pain, edited by AGH Gustafsson. New York, London: Routledge:33-56.

Simmel, G. 1950. The metropolis and the mental life, in The Sociology of Georg Simmel, edited by KH Wolff. Glencoe: The Free Press:409-424.

Sontag, S. 2003. Regarding the pain of others. New York: Farrar, Strauss \& Giroux. 